Discussion Paper No. 655

\title{
JAPANESE CORPORATE FINANCE: \\ WHAT FACTORS AFFECT \\ THE FINANCIAL DECISIONS \\ OF JAPANESE FIRMS?: \\ A SURVEY RESULT
}

Nobuyoshi Yamori

March 2006

The Institute of Social and Economic Research

Osaka University

6-1 Mihogaoka, Ibaraki, Osaka 567-0047, Japan 


\title{
Japanese Corporate Finance: What Factors Affect the
}

\section{Financial Decisions of Japanese Firms?:}

\section{A Survey Result}

\author{
Nobuyoshi Yamori \\ Graduate School of Economics, Nagoya University \\ Furo-cho, Chikusa-ku, Nagoya, Aichi 464-8601 Japan \\ Institute of Social and Economic Research, Osaka University \\ Mihogaoka, Ibaraki, Osaka 560-0047 Japan \\ (tel.)(+81)52-789-4935, (fax)(+81)52-789-4924, e-mail: yamori@soec.nagoya-u.ac.jp
}

\begin{abstract}
In June 2005, a questionnaire survey was sent to 9000 companies in the Kansai Area (Osaka, Kyoto and Hyogo), the second largest economic block in Japan, with 2041 companies responding. This article introduces the results of this questionnaire survey. The greatest feature of this study is that, unlike previous works on traditional corporate finance, much information on unlisted companies is included. The dividend policy of Japanese companies, awareness of corporate governance, funding behavior, and bank selection behavior were analyzed. As a result, we found that being a consolidated subsidiary or a group member of an affiliation of companies greatly affects a company's financial activities, and that the capital adequacy ratio and size of the company are also important factors.
\end{abstract}

JEL Classification Code: G32, G20.

Key Words: Japanese small firms; Financial decision; Main banks; Dividend policy; Corporate governance. 


\title{
Japanese Corporate Finance: What Factors Affect the Financial Decisions of Japanese Firms?:
}

\author{
A Survey Result
}

\section{Introduction}

Most research on corporate finance in Japan (e.g., Hoshi and Kashyap 2001, Kang and Stultz 1996) has been conducted only on listed companies and there are very few studies on unlisted companies due to the difficulty in obtaining data. However, according to a survey conducted by the Ministry of Internal Affairs and Communication in 2001, of $4,700,000$ companies (including sole proprietorships) in Japan, there are 4,690,000 smalland medium-sized companies and only 13,000 large companies ${ }^{1}$. Also in terms of the number of employees, $29,960,000$ (70.2\% of the total $42,660,000$ employees) work for small and medium-sized companies. In other words, without conducting an analysis of small- and medium-sized companies which constitute the majority of Japanese companies, it is impossible to understand the characteristics of Japanese companies or the Japanese economy. Therefore, an extensive questionnaire survey that covered small- and medium-sized companies is necessary ${ }^{2}$. Consequently, we conducted an "management survey of corporate finance issues in the Kansai Area" with the head offices of 9000 companies in the Kansai Area (Osaka, Kyoto and Hyogo Prefectures).

The gross production of the 3 prefectures in Kansai (FY2001) is JPY67.2 trillion in total, accounting for $13.4 \%$ of the total production in Japan, and the area is the second largest economic block in Japan after Tokyo. In addition, it is a common knowledge that there are many small- and medium sized companies in the area. However, since the failures of Kizu Credit Cooperative and Hyogo Bank in 1995, a number of small- and medium-sized financial institutions went bankrupt in the Kansai Area, and Sumitomo Bank (currently Sumitomo Mitsui Banking Corporation) and Sanwa Bank (currently the Bank of Tokyo Mitsubishi UFJ), city banks with head offices in Osaka, relocated their headquarters to Tokyo after reorganization. Another city bank, Daiwa Bank (currently Resona Bank) was nationalized, effective in 2003. In this way, the Kansai Area is also expected to be the area

\footnotetext{
1 "Small- and medium sized companies" are defined as companies with 300 regular employees or less (or, 100 or less for wholesalers and service businesses, and 50 or less for retailers and catering establishments) or, with a capital of JPY 300 million or less (or JPY 100 million or less for wholesalers and JPY 500 million or less for retailers, catering establishments and service businesses).

${ }^{2}$ Yamori and Baba (2001) analyzed the results of a questionnaire survey with listed companies in Japan regarding their overseas listing strategies.
} 
most affected by the impact of changes to the financial system across the country.

This article is divided into the following sections: Section II explains the summary of the questionnaire survey. Section III selects questions regarding the financial decision of the companies and analyzes how the answers to those questions are affected by the companies' attributes. Section IV is the conclusion.

\section{Summary of the Management Survey of Corporate Finance Issues in the Kansai Area}

(1) Selection of Responding Companies

Companies managed in the Tokyo Commerce and Industry Research database were used as the parent population, and, after excluding certain types of industry such as public utilities, companies were classified into 4 groups based on the number of employees (1-20, 21-50, 51-100 and 101 or more). Next, 2250 companies were randomly selected from each group, for a total of 9000 companies to which the survey form was to be sent. In June 2005, the survey form was sent to the 9000 companies, and the responses from 2041 companies received by July 1 were analyzed in this paper. Response rate was $22.68 \%$. However, some companies did not respond to each corresponding question, and a non-response was not included in the actual calculation of the figures and estimations, thus the number of the companies analyzed differs depending on the question.

\section{(2) Summary of the Survey Form}

The questions could be roughly divided into 8 Parts. Part I asks about the attributes of the person who responded to the survey. Part II asks about the attributes of the responding company. Part III contains questions regarding overall management of the responding company. Part IV inquires about overall financial policies. Part $V$ inquires about the relationship with the main bank. Parts VI, VII and VII contain questions regarding overall banking transactions, questions regarding methods of corporate assessment of small- and medium-sized companies by financial institutions, and questions regarding the credit guarantee system, respectively. Of these, the results of Part IV are mainly used for the discussion of this article.

(3) Situation of the Responding companies

Table 1 shows the number of responding companies according to the number of employees. The survey forms were sent to 2250 companies in each of the 4 categories based on the number of employees according to the rules for selection. Therefore, the size of the responding companies in the table directly represents the level of response rate. As expected, there were fewer responses from small companies with 1-20 employees. However, as there were 372 responses from companies in this group, the opinions of a wide range of companies can be expected. Of the total responding companies (2020 
companies), the largest and smallest number of employees was 22,724 and 1 , respectively, and the average number of employees is 147.9.

The number of valid answers to the question on listing status was 1969. Of these, $74(3.8 \%)$ companies were already "listed or public". Therefore, the remaining approx. 1800 companies were unlisted. However, 40 of them replied that "they have concrete plans for public offering" and 160 desired to go public although they had no concrete plans.

\section{Table 1}

Distribution of Responding Companies by Number of Employees

\begin{tabular}{|r|r|r|r|r|}
\hline $1 \sim 20$ & $21 \sim 50$ & $51 \sim 100$ & \multicolumn{1}{|c|}{$101 \sim$} & Unknown \\
\hline 372 & 554 & 574 & 520 & 21 \\
\hline $18.2 \%$ & $27.1 \%$ & $28.1 \%$ & $25.5 \%$ & $1.0 \%$ \\
\hline
\end{tabular}

Note: Actual numbers and the percentages are shown in the upper and the lower rows respectively.

\section{Analysis of the Questionnaire Results}

This section discusses and analyzes the survey questions regarding the financial decisions of Japanese companies. However, the numbering of the questions below was left the same as those of the original survey form. In addition, the survey form was originally prepared in Japanese. The following questions were translated for the purpose of this article.

Q7 What is the percentage of your capital adequacy ratio ( = Shareholders' Capital/Gross Assets on the balance sheet)? (Approximate figures are acceptable. Please provide the figures as of the end of the latest fiscal year.)

1. Capital adequacy ratio

2. Liability exceeding assets

Of 1811 valid answers, 78 companies (4.3\%) answered that they had liabilities in excess of assets. The average capital adequacy ratio of responding companies which did not have an excess of liabilities was $33.2 \%$, and the most common capital ratio for distribution was less than $20 \%$, as shown in Table 2. 
Table 2

Capital Adequacy Ratio

\begin{tabular}{|r|r|r|r|r|r|}
\hline \multicolumn{1}{|c|}{$\begin{array}{c}\text { Total Number of } \\
\text { Responses }\end{array}$} & $\begin{array}{c}\text { Less than } \\
20 \%\end{array}$ & $\begin{array}{c}20 \% \text { or more - Less } \\
\text { than } 40 \%\end{array}$ & $\begin{array}{c}40 \% \text { or more - Less } \\
\text { than } 60 \%\end{array}$ & $\begin{array}{c}60 \% \text { or more - Less } \\
\text { than } 80 \%\end{array}$ & $\begin{array}{c}80 \% \text { or } \\
\text { more }\end{array}$ \\
\hline 1715 & 675 & 444 & 321 & 178 & 97 \\
$100 \%$ & 39.4 & 25.9 & 18.7 & 10.4 & 5.7 \\
\hline
\end{tabular}

Q8. Please circle the appropriate number from the following lines which best describes your business achievement (profits before tax):

1. Posted profits for 2 consecutive fiscal years 2 . Went from a deficit to a profit

3. Went from a profit to a deficit 4. Posted losses for 2 consecutive fiscal years

Profit conditions before tax as an indicator of business achievement were asked. $74.2 \%$ of the respondents answered that they had posted profits for two consecutive fiscal years, so the percentage of profit-making companies was $84.3 \%$ for the current fiscal year. Given the general slowdown in business in Kansai, this was rather surprising. This may be due to the assumption that companies who were willing to answer the questionnaire had a comparatively good management strength, or as the database of companies to which the questionnaire was sent did not cover all companies, companies with poor management strength were likely not to be included; and approx. 200 companies that did not answer this question might experience poor performance.

\section{Table 3}

Status of Profit Before Tax

\begin{tabular}{|r|r|r|r|r|}
\hline $\begin{array}{c}\text { Total Number of } \\
\text { Responses }\end{array}$ & $\begin{array}{c}\text { Posted profits for 2 } \\
\text { consecutive fiscal years }\end{array}$ & $\begin{array}{c}\text { Went from a } \\
\text { deficit to a profit }\end{array}$ & $\begin{array}{c}\text { Went from a } \\
\text { profit to a deficit }\end{array}$ & $\begin{array}{c}\text { Posted losses for 2 } \\
\text { consecutive fiscal years }\end{array}$ \\
\hline 1987 & 1474 & 201 & 170 & 142 \\
$100 \%$ & 74.2 & 10.1 & 8.6 & 7.1 \\
\hline
\end{tabular}

Q9 Regarding the most recent dividend payment, did you:
1. Pay dividends
2. Did not pay dividends

According to the results of the questionnaire survey, 839 companies (42.7\%) paid dividends, while 1125 (57.3\%) did not.

There are many studies on corporate dividend policies ${ }^{3}$. For example, Gul(1999), Hayashi and Jagannathan(1990), and Kato and Loewenstein(1995) conducted studies on

${ }^{3}$ Lease, et. al.(2000) made an extensive survey of studies to date. 
Japanese companies. However, these studies only studied listed companies. Of course, it is well known that in a perfect capital market, dividend policy does not affect enterprise value. However, even in listed companies, most business managers believe that the dividend policy is an important issue for corporate decision-making. Unlike listed companies, the condition of a perfect capital market may not apply to unlisted companies but there are very few studies on unlisted companies.

Therefore, the kind of factors that determine payment or nonpayment of dividends for the companies which responded to this questionnaire survey, including a large number of unlisted companies, was investigated. A regression using a no-dividend dummy (NODIV) where 1 (one) is assigned as the dependent variable for responding companies that did not pay a dividend, and 0 (zero) is assigned for responding companies that paid dividends. Furthermore, in addition to listing status, the following various financial conditions of the companies were used as independent variables.

First is the condition where profits before tax occurred over the past two consecutive 2 fiscal years as asked in Question 8. Q08A2 is a dummy variable where 1 (one) is assigned to a company that went from a deficit to a profit (that is, companies choosing Answer 2 of Question 8) and 0 (zero) otherwise. Similarly, Q08A3 is a dummy variable where 1 (one) is assigned to a company that went from a profit to a deficit, and Q08A4 where 1 (one) is assigned to a company that posted losses for two consecutive fiscal years. Companies that posted profits for two consecutive fiscal years are used as a base, and the difference among these companies is shown as coefficients of these dummy variables. Since companies with deficits are likely to pay no dividend, these dummy variables are expected to be positive. Given the difficult financial situation, Q08A4's coefficient is expected to be the largest, followed by Q08A3 and then Q08A2.

Second, (although not described in this article) a dummy variable (Q10AA1) was included where 1 (one) was assigned to companies that answered "severe" to the question on latest funding and 0 (zero) to companies that answered otherwise. Since companies with difficulty in funding wish to avoid dividend payment as it represents an outflow of liquidity, the factor of this variable is expected to be positive.

Third, the latest sales growth (SGRW) was adopted as a measure to evaluate business performance. SGRW greater than 1 (one) represents sales during the latest fiscal year that exceed the results of the previous fiscal year. However, while some companies with growing sales do not pay dividends because they have a number of attractive investment opportunities, the likelihood to pay dividends also increases due to favorable business performance. As such, it is impossible to determine the sign of this factor in advance.

Fourth, the capital adequacy ratio (CAP) of a company was adopted ${ }^{4}$. Since

\footnotetext{
${ }^{4}$ Companies which responded that their capital adequacy ratio exceeded $100 \%$ were excluded, as they are suspected to be erroneous. For instance, in case of the analysis shown in Table 4, 12 companies were excluded from the samples due to this condition.
} 
undercapitalized companies are likely to place priority on internal accumulation of capital, the CAP factor is expected to be negative.

Fifth, the size of the company was added as an independent variable. In general, the larger the company is, the wider the gap between business managers and shareholders is. However, it is not always clear whether this will increase or decrease dividends. Here, we used the natural logarithm of gross assets (ASSET) as a size variable.

Sixth, a company's association with a business group may influence its dividend policy. In this questionnaire we asked the company whether it is a consolidated subsidiary with a parent company, a company with a parent company but not a consolidated subsidiary (referred to as an "affiliated company"), or an independent company. Therefore, Q04A1 is a dummy variable where 1 (one) is assigned to a consolidated subsidiary with a parent company and 0 (zero) otherwise, and Q04A2 is a dummy variable where 1 (one) is assigned to an affiliated company and 0 (zero) otherwise. In other words, independent companies are used as the base. If a parent company desires to absorb funds from its subsidiaries, the consolidated subsidiary is likely to pay dividends, and the factor of Q04A1 should be positive.

Last, there is a listed dummy. While there is a difference in the implementation method of capital gains between listed and unlisted companies, in the case of unlisted companies, business managers often are major shareholders so corporate governance may work differently from listed companies. Therefore, we use a listed dummy (LISTED) where 1 (one) is assigned to a listed company and 0 (zero) otherwise.

In addition, due to the nature of dependent variables, the probit model estimation was also conducted. Since not all companies answered all questions, the total number of samples was 1517 or less.

The results of the estimation are summarized in Table 4. Except for SGRW (sales growth), A04A1 (subsidiaries) and LISTED, statistically significant factors could be obtained. That is to say, companies which are in deficit (namely, Q08A2, Q08A3, and Q08A4) are likely to pay no dividend, and companies finding difficulties in funding (Q10AA1) or with a lower capital adequacy ratio (CAP) are likely to pay no dividend ${ }^{5}$. Furthermore, smaller companies (ASSET) are likely to pay no dividend. In addition, though there was no difference in dividend policies between consolidated subsidiaries and independent companies (Q04A1), affiliated companies (Q04A2) were less likely to pay no dividends as compared to independent companies.

The LISTED factor was not significant even at the $10 \%$ level, and no difference was found between listed and unlisted companies. To confirm this result, cross terms between all explained variables excluding LISTED and LISTED were added and the

5 Some companies reported positive but less than $1 \%$ capital ratio. We are afraid that they entered wrongly. So, we re-estimated the equation without companies reporting less than $1 \%$ capital ratio, and confirmed that the results remain qualitatively unchanged. 
non-dividend equation was re-estimated. In other words, whether the size of each independent variables is different between listed and unlisted companies was investigated. However, no additional cross terms became significant. Therefore, listing status is not considered to be a key factor in dividend payment.

\section{Table 4}

Results of Non-dividend Function Estimation

\begin{tabular}{|l|r|r|}
\hline Variable & Coefficient & z-Statistic \\
\hline C & 4.312 & 11.213 \\
\hline Q08A2 & 0.430 & 3.192 \\
\hline Q08A3 & 1.028 & 6.354 \\
\hline Q08A4 & 1.045 & 4.564 \\
\hline Q10AA1 & 0.649 & 5.809 \\
\hline SGRW & 0.036 & 0.235 \\
\hline CAP & -0.013 & -8.451 \\
\hline ASSET & -0.340 & -12.125 \\
\hline Q04A1 & -0.091 & -0.965 \\
\hline Q04A2 & -0.312 & -2.409 \\
\hline LISTED & -0.420 & -1.515 \\
\hline & & \\
\hline Log likelihood & & -797.732 \\
\hline McFadden & & 0.234 \\
\hline R-squared & & \\
\hline
\end{tabular}

Total observations $=1505$.

Q15 Which of the following groups do you currently consider important as a stakeholder? And, which stakeholder will you emphasize from now? Please circle the appropriate number(s) from the following for your current situation and future plans.

1. General customers

2. Employees

3. Individual investors

4. Domestic institutional investors

5. Foreign institutional investors

6. Main Bank

7. Business partners

8. Affiliated company group

9. Owner

10. Management 
To understand the basic stance on corporate governance, companies were asked about which stakeholder, present and future, was considered most important. Answers are shown in Table 5. For both questions, business partners were chosen as the most important stakeholders, followed by employees and general customers.

Difference in important groups is also quite interesting. Therefore, an analysis using the explanatory variables previously used to estimate the non-dividend function was conducted. The dependent variable of the first estimation is a dummy variable (Q15A1) where 1 (one) is assigned to companies that chose general customers as the current most important bodies and 0 (zero) to companies that did not choose general customers.

Similarly, an estimation using the probit model in order to explain 11 variables in total, such as a dummy variable (Q15A2) where 1 (one) is assigned to companies that chose employees was also conducted.

The results of the estimation are summarized in Table 6. A number of variables were found to influence the choice of the most important stakeholder. Companies which recently had experienced difficulties in funding (Q10AA1) were likely to attach importance to main banks and affiliated company groups, and in contrast, are less likely to put a high priority on employees. This may be because companies with difficulties in funding need the support of financial institutions or affiliated companies, while cutting back on personnel.

A company with higher capital adequacy ratio (CAP) tends to attach importance to general customers but to place less importance on main bank. This may be because companies with a higher capital adequacy ratio are less likely to be dependent on financial institutions. The larger the size of the company (ASSET) is, the more likelihood it is to place importance on main bank. This result is surprising as smaller companies are expected not to have someone else to rely upon other than the main bank.

Whether the company is a consolidated subsidiary (Q04A1) or an affiliated company (Q04A2) has a significant influence in determining the most important group. In case of consolidated subsidiaries, importance is attached to affiliate company groups, and less importance is placed on employees, main bank, or business partners. Placing strong emphasis on affiliate company groups can be expected since important labor, financial and operational decisions are made by the parent company. This is almost the same for affiliated companies, and the only difference is that a number of affiliated companies answered that they place importance on the management.

Lastly, the listing status also had great influence in terms of which group is considered important. Listed companies are likely to focus on individual investors and institutional investors, and tend to place less value on employees and business partners. 
Table 5

Most Important Entity

\begin{tabular}{|c|c|c|c|r|}
\hline & \multicolumn{2}{|c|}{ Present } & \multicolumn{2}{c|}{ Future } \\
\hline & $\begin{array}{c}\text { Number of } \\
\text { responses }\end{array}$ & Percentage & $\begin{array}{c}\text { Number of } \\
\text { responses }\end{array}$ & Percentage \\
\hline General Customers & 863 & 46.2 & 882 & 47.6 \\
\hline Employees & 908 & 48.6 & 942 & 50.8 \\
\hline Private Investors & 20 & 1.1 & 51 & 1.3 \\
\hline $\begin{array}{c}\text { Domestic Institutional } \\
\text { Investors }\end{array}$ & 22 & 1.2 & 24 & 0.2 \\
\hline $\begin{array}{c}\text { Overseas Institutional } \\
\text { Investors }\end{array}$ & 5 & 0.3 & 4 & 11.2 \\
\hline Main Bank & 239 & 12.8 & 208 & 51.9 \\
\hline Business Partners & 999 & 53.5 & 961 & 7 \\
\hline Affiliated Company Group & 123 & 6.6 & 129 & 4.8 \\
\hline Owner & 118 & 6.3 & 89 & 4.5 \\
\hline Management & 79 & 4.2 & 83 & 1.8 \\
\hline Other & 35 & 1.9 & 34 & \\
\hline
\end{tabular}

\section{Table 6}

Decision Function of the Most Important Entity

$<$ Attached to the back $>$

Q16 Please choose 3 from the following methods of external funding which you consider important, listing them in order of importance:

1. Procurement from the main bank

2. Procurement from financial institutions other than the main bank

3. Procurement from public-sector financial institutions

4. Institutional loans from municipalities, etc

5. Borrowing from a business partner (trade credits)

6. Short-term CPs

7. Long-term corporate bonds

8. Convertible bonds

9. Common stock

10. Subordinated bonds and preferred shares

11. Securitization of leases, credits and account receivables 
12. A Pledge of goods in stock

13. Other

For the percentage of the most important item selected (Table 7), most companies, 2 out of 3 , chose "procurement from the main bank", followed by companies which chose procurement from public-sector financial institutions.

A regression on the differences in funding sources by attributes of the companies was conducted. The following explanatory variables were used. Q16AF1 is a dummy variable where 1 (one) is assigned to companies that chose the "main bank" as the most important, and 0 (zero) to companies that chose otherwise. Similarly, Q16AF2 is a dummy variable where 1 (one) is assigned to companies that chose "procurement from financial institutions other than the main bank" as the most important and 0 (zero) to companies that chose otherwise. Other variables were similarly defined, and options 3 and 4 were grouped together since they both use a public source (A16AF3_4) and options 5 to 10 were grouped together as financing from the market (A16AF6_10). Furthermore, 11 and 12 were grouped together as they both are securitization (Q16AF11_12). An estimation by the probit model was performed.

The results are summarized in Table 8. It is surprising that companies who posted losses for two consecutive fiscal years (Q08A4) placed emphasis on funding from the financial market, because information asymmetry is particularly large for such companies and funding from the market appears to be disadvantageous. Companies with higher sales growth (SGRW) tend to attach importance to funding from the financial market. Companies with higher capital adequacy ratio (CAP) are likely to procure funds from their main banks, and companies with lower capital adequacy ratio tend to focus on financial institutions other than the main bank and public financing.

Furthermore, the larger the company (ASSET) becomes, the more likely importance is attached to the relationship with the main bank, while the smaller the assets are, the more focus there is on public financing. Consolidated subsidiaries (Q04A1) are likely to place importance on trade credits and securitization rather than the main bank and public financing. Finally, for listing status, listed companies naturally place importance on funding from the financial market and are less likely to attach importance to the main bank. 
Table 7

Important Financing Method

\begin{tabular}{|l|r|r|r|r|r|r|}
\hline & \multicolumn{2}{|r|}{1} & \multicolumn{2}{|r|}{3} \\
\hline Total & 1785 & 100.0 & 1654 & 100.0 & 1444 & 100.0 \\
\hline Procurement from the main bank & 1167 & 65.4 & 278 & 16.8 & 138 & 9.6 \\
\hline $\begin{array}{l}\text { Procurement from financial institutions other than the main } \\
\text { bank }\end{array}$ & 130 & 7.3 & 669 & 40.4 & 298 & 20.6 \\
\hline Procurement from public-sector financial institutions & 266 & 14.9 & 433 & 26.2 & 414 & 28.7 \\
\hline Institutional loans of municipalities, etc & 42 & 2.4 & 115 & 7.0 & 192 & 13.3 \\
\hline Borrowing from business partners & 20 & 1.1 & 9 & 0.5 & 21 & 1.5 \\
\hline Short-term CPs & 5 & 0.3 & 9 & 0.5 & 12 & 0.8 \\
\hline Long-term corporate bonds & 26 & 1.5 & 51 & 3.1 & 132 & 9.1 \\
\hline Convertible bonds & 3 & 0.2 & 16 & 1.0 & 17 & 1.2 \\
\hline Common shares & 31 & 1.7 & 23 & 1.4 & 40 & 2.8 \\
\hline Subordinated bonds and preferred shares & 4 & 0.2 & 3 & 0.2 & 6 & 0.4 \\
\hline Securitization of leases, credits and account receivables & 14 & 0.8 & 32 & 1.9 & 98 & 6.8 \\
\hline etc & 77 & 4.3 & 13 & 0.8 & 62 & 4.3 \\
\hline Pledging of goods in stock & & 0.0 & 3 & 0.2 & 14 & 1.0 \\
\hline Other & & & & \\
\hline
\end{tabular}

\section{Table 8}

Decision factor of the Most Important Financing Method

$<$ Attached to the back>

Q17 What is your plan for borrowing from financial institutions? Please circle the appropriate number:
1. Plan to decrease borrowings
2. Unchanged $\rightarrow$ go to $\mathrm{Q} 18$
3. Plan to increase
borrowings $\rightarrow$ Q18

Of 1804 valid responses, 1083 companies (60.0\%) chose "plan to decrease", 598 chose "unchanged", and 123 chose "plan to increase". We examined what factors affected these borrowing policies.

As the dependent variable, we used a dummy variable (Q17A1) where 1 (one) was assigned to companies that chose "plan to decrease" and 0 (zero) otherwise. The explanatory variables are the same as those previously used in the estimation of the non-dividend factor. According to the estimation results, the only significant factors were Q10AA1 which represents difficulty in funding and Q04A2 which represents the status as 
an affiliated company. In other words, only companies with difficulties in funding planned to decrease borrowings. This may be because these companies could not increase borrowings and be forced to pay back debts.

At the same time, another estimation using a dummy variable (Q17A3) where 1 (one) is assigned to companies that chose "plan to increase" and 0 (zero) otherwise as an dependent variable was also performed. According to the results, only the capital adequacy ratio (CAP) and affiliate companies dummy (Q04A2) were significant at the 10\% level. In other words, companies with a higher capital adequacy ratio are less likely to choose "plan to increase borrowings". This suggests that companies with sufficient equity capital do not rely on external funds.

Table 9

Decision Function for Borrowing from Financial Institutions

\begin{tabular}{|l|r|r|r|r|}
\hline & \multicolumn{1}{|c|}{ Planning to decrease } & \multicolumn{2}{l|}{ Planning to increase } \\
\hline Variable & Coefficient & z-Statistic & Coefficient & z-Statistic \\
\hline Q & 0.048 & 0.144 & -1.582 & -3.375 \\
\hline Q08A3 & -0.050 & -0.410 & 0.010 & 0.053 \\
\hline Q08A4 & -0.148 & -1.103 & 0.066 & 0.334 \\
\hline Q10AA1 & -0.277 & -1.587 & 0.298 & 1.297 \\
\hline SGRW & 0.180 & 1.854 & 0.093 & 0.682 \\
\hline CAP & 0.044 & 0.311 & 0.165 & 0.887 \\
\hline ASSET & -0.002 & -1.034 & -0.003 & -1.453 \\
\hline Q04A1 & 0.020 & 0.817 & 0.001 & 0.015 \\
\hline Q04A2 & -0.098 & -0.981 & -0.072 & -0.460 \\
\hline LISTED & -0.344 & -2.833 & 0.295 & 1.810 \\
\hline & -0.203 & -1.095 & -0.344 & -1.001 \\
\hline Log Likelihood & \multicolumn{5}{|l|}{-911.599} & & -351.509 \\
\hline McFadden & \multicolumn{7}{|l|}{0.010} & & 0.016 \\
R-squared & & & & \\
\hline
\end{tabular}

Observations $=1361$.

Q17-1 If you chose "1. plan to decrease borrowings" in Q17, please select the first and the second most appropriate reasons from the following:

1. The borrowing burden is substantially heavy due to deflation

2. Funding costs have increased

3. Have an excess of cash reserves but no new investment opportunity

4 To raise stock price

5. Borrowings are not good 
6. To reserve borrowing capacity in preparation of a new opportunity

7. Under pressure to repay borrowings from financial institutions

8. Limits have been placed on credits by banks

Valid responses for this question were $975\left(1^{\text {st }}\right)$ and $838\left(2^{\text {nd }}\right)$, respectively. As shown in Table 10, most companies chose "to reserve borrowing capacity in preparation of a new opportunity". 555 companies, representing approx $60 \%$ of the total, chose this as the first or the second answer. A questionnaire survey of US companies by Grahan and Harvey (2001) also reported that there was emphasis on financial flexibility among debt policy factors. This can be seen as a common tendency between Japan and the US. As shown in Table 10, this is followed by "having an excess of cash reserves but no new investment opportunity" and "the borrowing burden is substantially heavy due to deflation".

\section{Table 10}

Reasons to Decrease Borrowings

\begin{tabular}{|l|c|c|c|c|}
\hline \multirow{2}{*}{} & \multicolumn{2}{|c|}{1} & \multicolumn{2}{c|}{2} \\
\cline { 2 - 4 } & $\begin{array}{c}\text { Number of } \\
\text { responses }\end{array}$ & $\%$ & $\begin{array}{c}\text { Number of } \\
\text { responses }\end{array}$ & 12.2 \\
\hline $\begin{array}{l}\text { The borrowing burden is substantially heavy } \\
\text { due to deflation }\end{array}$ & 196 & 20.1 & 102 & 7.4 \\
\hline Funding costs have increased & 61 & 6.3 & 62 & 14.2 \\
\hline $\begin{array}{l}\text { Having an excess of cash reserves but no new } \\
\text { investment opportunity }\end{array}$ & 229 & 23.5 & 119 & 1.2 \\
\hline To raise the stock price & 10 & 1.0 & 10 & 185 \\
\hline Borrowings are not good & 190 & 19.5 & 305 & 36.4 \\
\hline $\begin{array}{l}\text { To reserve borrowing capacity in preparation of } \\
\text { a new opportunity }\end{array}$ & 250 & 25.6 & 22.1 \\
\hline $\begin{array}{l}\text { Under pressure to repay borrowings from } \\
\text { financial institutions }\end{array}$ & 25 & 2.6 & 19 & 2.3 \\
\hline Limits have been placed on credits by banks & 14 & 1.4 & 36 & 4.3 \\
\hline
\end{tabular}

Q18 To what extent do you agree with the description: "it is ideal to operate business without owing debts"? Please circle the appropriate number:
1. Strongly agree
2. Somewhat agree
3. Hardly agree
4. Totally disagree

Theoretically, as long as the investment opportunity produces a higher rate of earning than the interest payable, borrowing money is favorable. However, as borrowings increase, the company will be strapped with interest repayment issues. In Japan, which traditionally maintains a lifetime employment system, business managers shun the risk of corporate failure. Of 1878 responding companies, "strongly agree" ranked 28.6\%, "somewhat agree" $60.1 \%$, "hardly agree" $9.9 \%$, and "totally disagree" $1.3 \%$. It can be seen that most companies believe that operating business without owing debts is ideal.

A regression using the ordinary least-squares method was conducted. In the 
estimation, the results of the 4-scale assessment on the extent of agreement with the description: "it is ideal to operate business without owing debts" is a dependent variable. As a result shown in Table 11, significant factors were companies' size (ASSET) and the capital adequacy ratio (CAP). As the large-scale company factor became significantly positive, it could be seen that large-scale companies do not always believe that it ideal to operate business without owing debts. It is quite natural that large-scale companies do not agree with the irrational description which completely denies owing debts, as they should have more financial expertise. On the other hand, the coefficient of the capital adequacy ratio was significantly negative. This means that companies with higher capital adequacy ratio strongly maintain business operations without owing debts. This suggests that such orientation toward no debt business management is shown in actual practice.

\section{Table 11}

Extent of Agreement with the Description: "It is ideal to operate business without owing debts"

\begin{tabular}{|l|r|r|}
\hline Variable & Coefficient & t-Statistic \\
\hline C & 1.578 & 9.861 \\
\hline Q08A2 & 0.097 & 1.597 \\
\hline Q08A3 & 0.021 & 0.320 \\
\hline Q08A4 & 0.022 & 0.271 \\
\hline Q10AA1 & -0.069 & -1.458 \\
\hline SGRW & 0.072 & 1.067 \\
\hline CAP & -0.004 & -5.230 \\
\hline ASSET & 0.027 & 2.289 \\
\hline Q04A1 & -0.047 & -1.028 \\
\hline Q04A2 & 0.035 & 0.580 \\
\hline LISTED & 0.074 & 0.811 \\
\hline & & \\
\hline Adjusted & & 0.023 \\
\hline R-squared & & \\
\hline
\end{tabular}

Observations $=1414$

Q20 Do you plan to use direct finance?
1. No
2. Yes $\rightarrow$ go to Q21

254 companies (13.1\%) answered that they "plan to use" direct finance, while $1678(86.9 \%)$ answered "no". A regression was performed using a dummy variable (Q20A1) where 1 (one) is assigned to companies that "do not plan to use direct finance" and 0 (zero) to 
companies that "plan to use" direct finance as an dependent variable, and the explained variables are the same that have been previously used to represent the attributes of companies. The results of the estimation are shown in Table 12.

Significant variables were the capital adequacy ratio (CAP), the consolidated subsidiary dummy (Q04A1) and listed dummy (LISTED). The capital adequacy ratio was significantly positive, and, similar to question Q18, it could be seen that companies with higher capital adequacy ratio were reluctant not only to indirect but also direct finance. The consolidated subsidiary dummy is also significant as consolidated subsidiaries may not raise funds for themselves. The listed dummy was significantly negative, signifying that most listed companies are willing to use direct finance.

\section{Table 12}

Analysis of Attributes of Companies Which Do not Intend to Use Direct Finance

\begin{tabular}{|l|r|r|}
\hline Variable & Coefficient & z-Statistic \\
\hline C & 0.962 & 2.389 \\
\hline Q08A2 & -0.073 & -0.494 \\
\hline Q08A3 & 0.000 & -0.001 \\
\hline Q08A4 & -0.002 & -0.008 \\
\hline Q10AA1 & -0.061 & -0.531 \\
\hline SGRW & -0.300 & -1.864 \\
\hline CAP & 0.008 & 4.255 \\
\hline ASSET & 0.014 & 0.481 \\
\hline Q04A1 & 0.918 & 5.301 \\
\hline Q04A2 & 0.255 & 1.572 \\
\hline LISTED & -0.678 & -3.261 \\
\hline & & \\
\hline Log Likelihood & & -527.023 \\
\hline McFadden & & 0.066 \\
R-squared & & \\
\hline
\end{tabular}

Observations $=1462$.

Q20-1 If you chose "1. no" in Q20. Please circle appropriate number from the following choices that describes the main reason why you do not plan to use direct finance:

1. Have sufficient equity capital

2. Funding needs are met by indirect financing (from banks, etc)

3. Unsuitable for small scale/short-term funding

4. Not familiar with direct finance

5. Other ( ) 
Of 1678 responding companies that did not plan on using direct finance, 1616 companies replied to this question. Most companies, $52.4 \%$, answered that their "funding needs are met by indirect financing", followed by "sufficient equity capital" (23.3\%), "not familiar with direct finance" (12.3\%), "unsuitable for small scale/short-term funding" (6.6\%) and "other" $(5.4 \%)$.

In order to analyze selection determinants, a regression analysis was conducted by the probit model. The dependent variable Q20AB1 is a dummy variable where 1 (one) is assigned to companies that chose "we have enough equity capital" as "1" and 0 (zero) otherwise. Similarly, except for the "other" option at the bottom, Q20AB2, Q20AB3 and Q20AB4 were defined in the same way.

The results are summarized in Table 13. Most companies facing difficulties in latest funding(Q10AA1) cite "unsuitability in size or funding needs" and unfamiliarity as reasons. It is easily understood that companies with a higher capital adequacy ratio chose "sufficient equity capital". Large-scale companies are more likely to answer "needs met by indirect finance" ${ }^{6}$. In addition, large-scale companies are less likely to answer "not familiar with direct finance". Graham and Harvey(2001) pointed out, in their questionnaire survey conducted on US companies, that there is a correlation between the size of a company and its financial knowledge and that this may be a factor in the company size anomaly. A similar possibility can be pointed out in Japan. Finally, most listed companies answered that they had "sufficient equity capital".

\section{Table 13}

Reasons Why Direct Finance is not used.

$<$ Attached to the back>

Q22 Do you have a cross-shareholding relationship with any business corporation or financial institution? Please circle the appropriate number in the answer column.

It is well known that cross-shareholding is quite common among listed companies in Japan, and cross shareholding constitutes the core of corporate grouping. There are many studies on cross-shareholding and corporate affiliation at the listed company level (e.g., Osano, 1996; Flash 1996). However, there are few studies on mutual shareholding of unlisted companies.

According to answers to Q22, 258 (14.1\%) out of 1835 companies answered that they had cross shareholding relationships with business corporations, and 127 (7.0\%) out

${ }^{6}$ However, it is notable that this analysis is conducted only on companies which did not plan to use direct finance. 
of 1815 companies with financial institutions. More companies have cross shareholding relationships with business corporations than with financial institutions.

To consider what kind of firms tend to have cross shareholding relationships, we estimate the equation, using a dummy variable (Q23AA) where 1 (one) is assigned to companies that said that they had cross shareholding relationships with business corporations and 0 (zero) to companies that answered "No" or "Don't know". As shown in Table 14, a smaller number of companies that posted losses for two consecutive fiscal years (Q08A4) had cross shareholding relationships, while most large-scale companies held shares mutually. In addition, listed companies, as well as affiliated companies are likely to have cross shareholding relationships. On the other hand, consolidated subsidiaries are less likely to have cross shareholding relationships.

A similar analysis was conducted on cross shareholding with financial institutions. In this case, it was also shown that a number of large-scale companies and listed companies have cross shareholding relationships with financial institutions. Furthermore, it is notable that the coefficient of consolidated companies dummy (Q04A1) is significantly negative, while that of affiliated companies (Q04A2) is not significant. In addition, listed companies more likely have cross shareholding relationship with financial institutions.

\section{Table 14}

Determinant for Cross Shareholding

\begin{tabular}{|c|c|c|c|c|}
\hline \multirow[b]{2}{*}{ Variable } & \multicolumn{2}{|c|}{$\begin{array}{l}\text { Cross shareholding with Business } \\
\text { Corporations }\end{array}$} & \multicolumn{2}{|c|}{$\begin{array}{l}\text { Cross shareholding with Financial } \\
\text { Institutions }\end{array}$} \\
\hline & Coefficient & z-Statistic & Coefficient & z-Statistic \\
\hline C & -3.317 & -7.168 & -4.958 & -6.952 \\
\hline Q08A2 & 0.005 & 0.030 & -0.256 & -0.893 \\
\hline Q08A3 & -0.152 & -0.842 & -0.072 & -0.273 \\
\hline Q08A4 & -0.637 & -2.104 & 0.148 & 0.497 \\
\hline Q10AA1 & 0.017 & 0.128 & 0.065 & 0.352 \\
\hline SGRW & -0.155 & -0.755 & -0.334 & -1.013 \\
\hline CAP & 0.002 & 1.264 & 0.001 & 0.259 \\
\hline ASSET & 0.190 & 5.932 & 0.301 & 6.328 \\
\hline Q04A1 & -0.253 & -2.043 & -1.365 & -3.936 \\
\hline Q04A2 & 0.491 & 3.522 & -0.329 & -1.249 \\
\hline LISTED & 0.943 & 4.771 & 1.592 & 6.967 \\
\hline Log Likelihood & & -523.983 & & -239.597 \\
\hline $\begin{array}{l}\text { McFadden } \\
\text { R-squared }\end{array}$ & & 0.134 & & 0.369 \\
\hline
\end{tabular}

Observation=1406. 
Q23 Do you currently have a main bank? Please circle the appropriate number:

$\begin{array}{ll}\text { 1. Yes } & \text { 2. No }\end{array}$

One characteristic of the Japanese financial system that has been pointed out is the existence of a long-term stable relationship between the bank and the company, commonly known as the main bank relationship (Hoshi and Kashyap 2001). Generally speaking, the main bank is the largest lending bank and is also a major shareholder for the company. The main bank sometimes sends in directors to the company. However, such strict interpretation of a main bank was not defined prior to requesting an answer, and companies were asked whether they had "a main bank" without any limitations. As such, the idea of a main bank may differ slightly depending on the responding company, but the question took advantage of the questionnaire survey feature of corporate awareness rather than simple numeric values.

As a result, of 2015 valid answers, 1799 companies (89.3\%) responded that they have "a main bank", while 216(10.7\%) answered that they did not. The types of companies that have a main bank was examined by a regression model using a dummy variable (Q23A1) where 1 (one) is assigned to companies with a main bank and 0 (zero) otherwise. According to the results of the estimation as shown in Table15, 3 variables, namely size, the consolidated subsidiary(Q04A1) and the affiliated company (Q04A2) variables were significant. A significantly positive coefficient was obtained for the size variable, meaning that large-scale companies are likely to have a main bank. On the other hand, coefficients of Q04A1 and Q04A2 are negative, meaning that for consolidated subsidiaries and affiliated companies, they do not have main banks because their parent companies carry out the financial function. 
Table 15

Attributes of Companies that have a Main bank

\begin{tabular}{|l|r|r|}
\hline Variable & Coefficient & z-Statistic \\
\hline C & 0.910 & 2.243 \\
\hline Q08A2 & 0.183 & 1.052 \\
\hline Q08A3 & -0.170 & -1.047 \\
\hline Q08A4 & -0.286 & -1.426 \\
\hline Q10AA1 & -0.011 & -0.087 \\
\hline SGRW & -0.086 & -0.532 \\
\hline CAP & -0.003 & -1.568 \\
\hline ASSET & 0.065 & 2.154 \\
\hline Q04A1 & -0.781 & -7.478 \\
\hline Q04A2 & -0.381 & -2.551 \\
\hline LISTED & -0.193 & -0.770 \\
\hline \multicolumn{2}{|l}{} \\
\hline Log Likelihood & \multicolumn{2}{|l}{0.064} \\
\hline McFadden & & \\
R-squared & &
\end{tabular}

Observations $=1509$.

Q24 Please circle the appropriate number of the business category of your main bank:

1. City bank

2. Trust Bank/now-defunct Long-term Credit Bank

3. Regional Bank

4. Second-tier Regional Bank

5. Cooperative Bank (Shinkin Bank)

6. Credit Cooperation

7. Foreign Bank

8. Government-affiliated Financial Institution

9. Other (

Regarding the business category of the main bank, 1085 (61.6\%) companies chose city banks, followed by 284 (16.1\%) for Regional Banks, and 259 (14.7\%) for Cooperative Banks. Only a few companies chose others, 58 (3.3\%) for Government-affiliated Financial Institutions, 53 (3.0\%) for Second-tier Regional Banks, 7 (0.4\%) for Credit Corporations and $1(0.1 \%)$ for Foreign Banks. City banks have a high share because city banks such as Sumitomo, Sanwa, Daiwa and Taiyo Kobe had held head offices in Osaka and Hyogo, where this questionnaire survey was conducted. Also, since many second-tier regional 
banks in Kansai went bankrupt, their share is slightly lower.

Next, how companies chose the business category of their main banks was examined. Here, options were sorted and a regression was conducted for 3 explained variables: a dummy variable (Q24A1_2) where 1 (one) is assigned for companies whose main bank is a major bank (city, trust and long-term credit bank) (that is, companies that answered 1 or 2) and 0 (zero) otherwise; a dummy variable (Q24A3_4) where 1 (one) is assigned for companies whose main bank is a local bank (regional or second-tier regional bank) and 0 (zero) otherwise; and, a dummy variable (Q24A5_6) where 1 (one) is assigned for companies whose main bank is a cooperative financial institution (credit bank or corporation) and 0 (zero) otherwise.

The results are shown in Table 16. Status of recent profits (Q08A2, Q08A3 and Q08A4) did not influence the selection of the business category of the main bank. This is natural because main bank relationship is long term. Companies facing difficulties in funding are more likely to choose cooperative financial institutions as their main bank. The causal relationship may be reversed here; since asset assessment of major banks is strict, companies with weak financial condition may choose cooperative financial institutions as their main bank. In fact, companies with higher capital adequacy ratio choose a major bank as their main bank, and, in contrast, companies with lower capital adequacy ratio choose a cooperative financial institution as their main bank. Large-scale companies are likely to choose a major bank and in contrast, smaller companies choose a cooperative financial institution. Companies with higher sales growth often may choose cooperative financial institutions as their main banks because most of them are in relatively early stages of growth. Lastly, consolidated subsidiaries and affiliated companies often choose a major bank as their main bank. This is probably because they choose the same bank as their parent company. 
Table 16

Type of Banks Chosen as the Main bank

\begin{tabular}{|c|c|c|c|c|c|c|}
\hline \multirow[b]{2}{*}{ Variable } & \multicolumn{2}{|l|}{ Major Bank } & \multicolumn{2}{|l|}{ Local Bank } & \multicolumn{2}{|c|}{$\begin{array}{l}\text { Cooperative Financial } \\
\text { Institution }\end{array}$} \\
\hline & Coefficient & z-Statistic & Coefficient & z-Statistic & Coefficient & z-Statistic \\
\hline C & -2.462 & -6.376 & 1.032 & 2.558 & 1.465 & 3.079 \\
\hline Q08A2 & 0.103 & 0.778 & -0.001 & -0.008 & -0.229 & -1.348 \\
\hline Q08A3 & -0.089 & -0.609 & 0.070 & 0.448 & -0.224 & -1.131 \\
\hline Q08A4 & -0.081 & -0.434 & 0.222 & 1.160 & -0.205 & -0.896 \\
\hline Q10AA1 & -0.338 & -3.348 & -0.058 & -0.519 & 0.529 & 4.508 \\
\hline SGRW & -0.175 & -1.004 & -0.064 & -0.326 & 0.468 & 2.164 \\
\hline CAP & 0.007 & 4.126 & -0.003 & -1.937 & -0.006 & -2.848 \\
\hline ASSET & 0.236 & 8.504 & -0.143 & -4.942 & -0.255 & -7.153 \\
\hline Q04A1 & 0.572 & 4.891 & -0.397 & -3.009 & -0.567 & -3.167 \\
\hline Q04A2 & 0.334 & 2.420 & -0.101 & -0.681 & -0.475 & -2.303 \\
\hline LISTED & 0.449 & 1.483 & -0.300 & -0.999 & -7.073 & 0.000 \\
\hline Log Likelihood & & -751.034 & & -608.992 & & -410.000 \\
\hline $\begin{array}{l}\text { McFadden } \\
\text { R-squared }\end{array}$ & & 0.117 & & 0.045 & & 0.145 \\
\hline
\end{tabular}

Observations $=1320$.

\section{Conclusion}

This article analyzed the determinants of financial activities of Japanese companies based on the results of the questionnaire survey sent to 9000 companies in Kansai in June 2005. This questionnaire survey was quite extensive and response was received from 2041 companies including small- and medium-sized unlisted companies. The dividend policy of Japanese companies, awareness of corporate governance, funding behavior and bank selection behavior, were analyzed in this paper. As a result, the paper found that the status as a consolidated subsidiary or a group member of an affiliation of companies greatly influences the financial activities of a company, and that the capital adequacy ratio and the size of the company are also important factors.

However, this one-time questionnaire survey could not fully evaluate the meaning of the answers to each question absolutely. Furthermore, it is impossible to determine whether the results at this time are applicable to Japanese companies in general, or only to companies in the Kansai Area. Similar questionnaire surveys should be conducted on an ongoing basis to examine the impact of changes in the economic environment. In addition, it is also necessary to conduct a questionnaire survey in various regions in Japan as well 
as overseas, in order to identify financial characteristics according to region. Finally, as pointed out by Graham and Harvey (2001), although such questionnaire surveys can solicit opinions from companies, there is no guarantee that their answers correspond to their actions. In this questionnaire survey, we often find that several answers are consistent with their actions. However, a further analysis of the actual actions of the companies is necessary in the future.

<Acknowledgements>

I would like to express my appreciation to the Regional Finance Research Group of the Research Institute of Economy, Trade and Industry (Chief Examiner: Professor Yoshiro Tsutsui, Osaka University) for their support for this questionnaire survey, which is the basis of this article.

$<$ References $>$

Flath, D. I. (1996) "The Keiretsu Puzzle," Journal of the Japanese and International Economies 10(2): 101-21.

Graham, J. R., and C.R. Harvey (2001) "The theory and practice of corporate finance: evidence from the filed," Journal of Financial Economics 60, 187-243.

Gul, F. A. (1999) "Growth Opportunities, Capital Structure and Dividend Policies in Japan," Journal of Corporate Finance 5(2): 141-68.

Hayashi, F., and R. Jagannathan (1990) "Ex-Day Behavior of Japanese Stock Prices: New Insights from New Methodology," Journal of Japanese and International Economics 4, 401-427.

Hoshi,T. and A. K. Kashyap (2001) Corporate financing and governance in Japan: The road to the future, Cambridge and London: MIT Press.

Kang,J. K. and R. M. Stulz (1996) "How Different Is Japanese Corporate Finance? An Investigation of the Information Content of New Security Issues," Review of Financial Studies 9(1): 109-39.

Kato, K., and U. Loewenstein (1995) "The Ex-Dividend-Day Behavior of Stock Prices: The Case of Japan," Review of Financial Studies 8, 817-847.

Lease, R. C., K. John, A. Kalay, U. Loeweinstein, and O H. Sarig, (2000) Dividend Policy, Harvard Business School Press, Boston.

Osano, H. (1996) "Intercorporate Shareholdings and Corporate Control in the Japanese Firm," Journal of Banking and Finance, Vol.20, pp.1047-1068.

Yamori, N. and T. Baba (2001) "Japanese Management Views on Overseas Exchange Listings: Survey Results," Journal of International Financial Management and Accounting 12-3 286-316. 
Table 6

Decision Function of the Most Important Body

\begin{tabular}{|c|c|c|c|c|c|c|c|c|c|c|c|c|c|c|c|c|c|c|c|c|}
\hline \multirow[b]{2}{*}{ Variable } & \multicolumn{2}{|c|}{$\begin{array}{l}\text { General } \\
\text { Customers }\end{array}$} & \multicolumn{2}{|c|}{ Employees } & \multicolumn{2}{|c|}{$\begin{array}{l}\text { Private } \\
\text { Investors }\end{array}$} & \multicolumn{2}{|c|}{$\begin{array}{l}\text { Domestic } \\
\text { Institutional } \\
\text { Investors }\end{array}$} & \multicolumn{2}{|c|}{$\begin{array}{l}\text { Overseas } \\
\text { Institutional } \\
\text { Investors }\end{array}$} & \multicolumn{2}{|c|}{ Main bank } & \multicolumn{2}{|c|}{$\begin{array}{l}\text { Business } \\
\text { Partners }\end{array}$} & \multicolumn{2}{|c|}{$\begin{array}{l}\text { Affiliated } \\
\text { Company } \\
\text { Group }\end{array}$} & \multicolumn{2}{|l|}{ Owner } & \multicolumn{2}{|c|}{ Management } \\
\hline & Coefficient & z-Statistic & Coefficient & z-Statistic & Coefficient & z-Statistic & Coefficient & z-Statistic & Coefficient & z-Statistic & Coefficient & z-Statistic & Coefficient & z-Statistic & Coefficient & z-Statistic & Coefficient & z-Statisicic & Coefficient & z-Statistic \\
\hline C & -0.582 & -1.890 & 0.001 & 0.004 & -2.299 & -2.318 & -1.799 & -1.834 & -4.265 & -1.471 & -2.314 & -5.003 & -0.032 & -0.102 & -2.696 & -4.708 & -1.738 & -3.185 & -0.569 & -0.916 \\
\hline Q08A2 & 0.013 & 0.110 & 0.003 & 0.027 & 0.262 & 0.711 & 0.108 & 0.300 & -6.728 & 0.000 & 0.183 & 1.198 & 0.105 & 0.903 & -0.436 & -1.819 & -0.403 & -1.590 & -0.286 & -1.114 \\
\hline Q08A3 & 0.022 & 0.172 & -0.013 & -0.101 & 0.429 & 1.250 & 0.032 & 0.074 & -6.308 & 0.000 & 0.166 & 1.001 & -0.068 & -0.545 & -0.162 & -0.696 & 0.265 & 1.480 & -0.422 & -1.364 \\
\hline Q08A4 & 0.152 & 0.949 & -0.136 & -0.840 & -18.881 & 0.000 & -0.052 & -0.092 & -6.248 & 0.000 & 0.228 & 1.143 & -0.016 & -0.100 & -0.074 & -0.240 & -0.171 & -0.596 & -0.292 & -0.869 \\
\hline Q10AA1 & -0.061 & -0.661 & -0.288 & -3.107 & -0.111 & -0.274 & -0.223 & -0.551 & -5.722 & 0.000 & 0.554 & 5.080 & 0.046 & 0.503 & 0.395 & 2.400 & 0.010 & 0.064 & 0.025 & 0.142 \\
\hline SGRW & 0.193 & 1.470 & 0.088 & 0.667 & 0.264 & 0.814 & 0.025 & 0.063 & -0.574 & -0.322 & -0.369 & -1.623 & -0.117 & -0.850 & 0.082 & 0.453 & -0.388 & -1.309 & -0.413 & -1.152 \\
\hline CAP & 0.003 & 2.137 & 0.000 & 0.192 & 0.006 & 1.278 & 0.004 & 0.913 & -0.011 & -0.864 & -0.013 & -5.891 & 0.000 & 0.051 & 0.004 & 1.463 & 0.002 & 0.980 & 0.002 & 0.699 \\
\hline ASSET & 0.012 & 0.522 & -0.004 & -0.185 & -0.063 & -0.877 & -0.079 & -1.135 & 0.175 & 0.977 & 0.154 & 4.773 & 0.021 & 0.956 & 0.020 & 0.481 & 0.042 & 1.148 & -0.069 & -1.609 \\
\hline Q04A1 & -0.125 & -1.446 & -0.245 & -2.822 & -0.574 & -1.305 & -0.150 & -0.460 & -6.796 & 0.000 & -0.981 & -5.500 & -0.202 & -2.354 & 1.616 & 12.317 & -0.097 & -0.660 & -0.257 & -1.294 \\
\hline Q04A2 & -0.174 & -1.486 & -0.045 & -0.386 & -19.008 & 0.000 & -0.009 & -0.025 & -6.926 & 0.000 & -0.427 & -2.284 & -0.184 & -1.582 & 0.970 & 5.393 & 0.280 & 1.675 & 0.361 & 1.994 \\
\hline LISTED & 0.154 & 0.874 & -0.502 & -2.750 & 1.858 & 5.109 & 2.036 & 5.824 & 0.923 & 1.133 & -0.401 & -1.525 & -0.726 & -3.914 & 0.220 & 0.728 & -0.788 & -1.893 & -6.058 & 0.000 \\
\hline Log likelihood & & 031.658 & & 037.600 & & -69.542 & & -78.581 & & -14.856 & & -479.921 & & 040.866 & & -282.399 & & -324.471 & & -222.956 \\
\hline McFadden R-squared & & 0.007 & & 0.013 & & 0.319 & & 0.317 & & 0.315 & & 0.135 & & 0.012 & & 0.256 & & 0.027 & & 0.044 \\
\hline
\end{tabular}

Observations $=1521$ 
Table 8

Decision Function of the Most Important Funding Method

\begin{tabular}{|c|c|c|c|c|c|c|c|c|c|c|c|c|}
\hline \multirow[b]{2}{*}{ Variable } & \multicolumn{2}{|l|}{ Main bank } & \multicolumn{2}{|c|}{$\begin{array}{l}\text { Financial Institutions } \\
\text { other than Main bank }\end{array}$} & \multicolumn{2}{|c|}{ Public financing } & \multicolumn{2}{|c|}{ Inter-company credits } & \multicolumn{2}{|c|}{ Financial market } & \multicolumn{2}{|c|}{ Securitization } \\
\hline & Coefficient & z-Statistic & Coefficient & z-Statistic & Coefficient & z-Statistic & Coefficient & z-Statistic & Coefficient & z-Statistic & Coefficient & z-Statistic \\
\hline $\mathrm{C}$ & -0.355 & -1.030 & -2.276 & -4.492 & 1.497 & 3.563 & -2.774 & -2.623 & -2.721 & -4.481 & -3.862 & -2.832 \\
\hline Q08A2 & -0.059 & -0.469 & -0.367 & -1.707 & 0.285 & 1.994 & -0.024 & -0.058 & -0.445 & -1.377 & 0.365 & 0.988 \\
\hline Q08A3 & -0.067 & -0.493 & -0.284 & -1.283 & 0.195 & 1.233 & 0.386 & 1.139 & 0.003 & 0.013 & -0.040 & -0.087 \\
\hline Q08A4 & -0.249 & -1.425 & -0.437 & -1.272 & 0.191 & 0.948 & 0.301 & 0.563 & 0.580 & 2.296 & -6.149 & 0.000 \\
\hline Q10AA1 & -0.105 & -1.075 & -0.087 & -0.598 & 0.211 & 1.902 & -0.094 & -0.285 & -0.096 & -0.485 & 0.086 & 0.238 \\
\hline SGRW & -0.312 & -2.042 & 0.208 & 1.167 & -0.008 & -0.043 & 0.418 & 1.773 & 0.392 & 2.149 & -0.832 & -1.200 \\
\hline CAP & 0.002 & 1.396 & -0.008 & -3.138 & -0.002 & -1.229 & 0.000 & 0.063 & 0.001 & 0.223 & -0.001 & -0.254 \\
\hline ASSET & 0.098 & 3.953 & 0.077 & 2.069 & -0.210 & -6.783 & -0.050 & -0.629 & 0.039 & 0.871 & 0.160 & 1.653 \\
\hline Q04A1 & -0.527 & -5.496 & -0.011 & -0.079 & -0.693 & -4.274 & 1.452 & 5.542 & -0.268 & -1.332 & 0.817 & 3.237 \\
\hline Q04A2 & 0.150 & 1.165 & 0.018 & 0.100 & -0.263 & -1.621 & -5.352 & 0.000 & -0.078 & -0.332 & -6.159 & 0.000 \\
\hline LISTED & -0.929 & -4.970 & -0.094 & -0.352 & -0.442 & -1.010 & -6.186 & 0.000 & 1.320 & 5.517 & 0.514 & 1.131 \\
\hline Log Likelihood & & -850.754 & & -365.460 & & -518.996 & & -70.984 & & -216.332 & & -55.662 \\
\hline $\begin{array}{l}\text { McFadden } \\
\text { R-squared }\end{array}$ & & 0.039 & & 0.034 & & 0.106 & & 0.291 & & 0.154 & & 0.191 \\
\hline
\end{tabular}

Observations=1372. 
Table 13

Reasons Why Direct Finance is not Used

\begin{tabular}{|c|c|c|c|c|c|c|c|c|}
\hline \multirow[b]{2}{*}{ Variable } & \multicolumn{2}{|c|}{$\begin{array}{l}\text { Sufficient equity } \\
\text { capital }\end{array}$} & \multicolumn{2}{|c|}{ Met by indirect finance } & \multicolumn{2}{|c|}{$\begin{array}{l}\text { Unsuitable for small } \\
\text { scale / short-term } \\
\text { financing }\end{array}$} & \multicolumn{2}{|l|}{ Unfamiliar } \\
\hline & Coefficient & z-Statistic & Coefficient & z-Statistic & Coefficient & z-Statistic & Coefficient & z-Statistic \\
\hline C & -0.847 & -2.039 & -0.527 & -1.457 & -2.344 & -3.829 & 0.758 & 1.476 \\
\hline Q08A2 & -0.007 & -0.041 & -0.298 & -2.229 & -0.014 & -0.067 & 0.398 & 2.477 \\
\hline Q08A3 & -0.380 & -1.994 & -0.016 & -0.112 & 0.164 & 0.775 & 0.330 & 1.903 \\
\hline Q08A4 & 0.509 & 2.350 & -0.521 & -2.697 & -0.663 & -1.537 & 0.308 & 1.349 \\
\hline Q10AA1 & -1.195 & -5.909 & -0.341 & -3.173 & 0.672 & 4.480 & 0.678 & 5.548 \\
\hline SGRW & 0.129 & 0.743 & 0.046 & 0.292 & 0.155 & 0.636 & -0.570 & -2.049 \\
\hline CAP & 0.020 & 11.369 & -0.010 & -6.493 & -0.005 & -1.722 & -0.010 & -4.392 \\
\hline ASSET & -0.066 & -2.205 & 0.098 & 3.783 & 0.051 & 1.147 & -0.110 & -3.095 \\
\hline Q04A1 & 0.732 & 6.974 & -0.721 & -7.411 & -0.228 & -1.321 & -0.435 & -2.710 \\
\hline Q04A2 & 0.072 & 0.461 & -0.052 & -0.389 & -0.082 & -0.361 & -0.138 & -0.713 \\
\hline LISTED & 0.597 & 2.743 & -0.553 & -2.663 & 0.068 & 0.199 & -5.990 & 0.000 \\
\hline Log Likelihood & & -551.152 & & -779.282 & & -239.774 & & -354.929 \\
\hline $\begin{array}{l}\text { McFadeen } \\
\text { R-squared }\end{array}$ & & 0.203 & & 0.081 & & 0.068 & & 0.166 \\
\hline
\end{tabular}

Observations $=1228$. 